\title{
調查報告
}

\section{若年労働者のコンビニエンスストアを利用した食事摂取内容と 労働状況に関する実態調査}

\author{
宮腰美希 ${ }^{1}$, 大塚美佳 ${ }^{2}$, 加藤めぐみ ${ }^{3}$ ， 久保智春 ${ }^{4}$, 土橋佳代子 ${ }^{5}$ ，豊島宏美 ${ }^{6}$, \\ 宮崎絵理子 ${ }^{7}$, 吉江 歩 $^{8}$, 大倉美佳 ${ }^{9}$, 表志津子 ${ }^{9}$, 城戸照彦 ${ }^{9}$ \\ ${ }^{1}$ 金沢大学大学院医学系研究科保健学専攻, ${ }^{2}$ 金沢市元町福祉健康センター, ${ }^{3}$ 金沢大学医学部付属病院, \\ ${ }^{4}$ 金沢有松病院， ${ }^{5}$ 京都府立医科大学付属病院， ${ }^{6}$ 能登北部保健福祉センター, \\ ${ }^{7}$ 金沢市駅西福祉健康センター, ${ }^{8}$ 大阪赤十字病院, ${ }^{9}$ 金沢大学医薬保健研究域保健学系
}

\section{抄録：若年労働者のコンビニエンスストアを利用した食 事摂取内容と労働状況に関する実態調查：宮腰美希ほ} か. 金沢大学大学院医学系研究科保健学専攻一本研究は, 若年労働者のコンビニエンスストア（以下コンビニとす る）を利用した食事摄取内容と労働状況に関する穾態を 明らかにすることを目的とし，肥満予防について検討し た。一輸送関連企業の石川県内に勤務する29歳以下の 労働者 284 人を対象に，無記名自記式質問紙を用いて調 查を行い，193 人の回答を得た。年の結果，労働状況の うち業務形態, 泊りの有無, 拘束時間の長さとコンビニ の利用の有無に関連があったが，労働状況とコンビニを 利用した食事摂取内容には明らかな関連はみられなかっ た、しかし，ほとんどの労働状況でコンビニを利用して 摄取した 1 食あたりの平均脂質割合が $25 \%$ を超えてい るという特徵があり，また，摂取頻度が高い食品は脂質 割合が高いものが多いという結果が得られた。これらの ことは肥満のリスクとなることが推測される。ささらに， 1 週間のコンビニの利用日数が多いほど, 食生活に対し 「改善が必要だと思う」と考えている人の割合が有意に 高くなっていた．以上のことから，若年労働者に対して 肥満予防への支援が必要であると考える。若年労働者が 栄養表示を確認し，食品を選択できるような支援をして いくこと，また，食品に栄養表示がされるようコンビニ 側に働きかけることにより，情報を入手しやすい環境を 整えることが求められる.

2007 年 11 月 12 日受付；2008年 3 月 14 日受理 J-STAGE 早期公開日：2008年 5 月 2 日

連絡先：宮腰美希 = 920-0942 石川県金沢市小立野 5-11-80 金沢大学大学院医学系研究科保健学専攻看護科学領域 (e-mail : miki2019@hotmail.com)
(産衛誌 2008; 50: 92-99)

キーワード : Young workers, Convenience stores, Meal, Working situations, Obesity

\section{I 、はじめに}

生活習慣病の䍜患率が増加しており，その予防のため に食事, 運動, 休養などの生活習慣を整える必要がある. しかし，白石ら ${ }^{1)}$ は若年者の食生活には朝食を抜きが ちで, 21 時以降に食事をとる頻度が高いという特徽や， 栄養バランスや塩分制限への配慮が 40 歳以上に比べて 少ないという特徴を報告している。また，食物摄取状況 の悪い群はその他の生活習慣も悪い ${ }^{2)}$ という結果が得 られて抢り,食生活が生活習慣全般に影響するといえる. このような乱れが肥満やメタボリックシンドローム等の 生活習慣病に罹患するリスクを高めることに影響すると 考えられ，若年者に対して健康教育，保健指導を行う必 要性が報告されている ${ }^{1-4)}$.

一方，コンビニの店舗数は増加しており ${ }^{5)}$ ，ますます コンビニを利用しやすい状況となっている。実際，20 歳代では週 3 回以上利用している者の割合が多く ${ }^{6)}$, 食 事のための利用も増加していると考えられる，そこで若 年者の食生活の中でもコンビニを利用した食事摂取内容 について着目した。

さらに，若年成人男性の入社後の体重変動を調查した 研究では対象者の約 9 割は体重が増加しており, 3 割近 くに $10 \mathrm{~kg}$ 以上増加し, 成人後の環境が肥満を誘発しや すいという結果を報告している ${ }^{4)}$. よって，若年者の中 でも労働者は, 労働時間や業務形態等の労働状沉が食生 活にも何らかの影響を及ほしているのではないかと考え 
られ，その生活が今後も継続されていくことが推測され る。職種別の食生活では, エネルギー, 脂質, 糖分等の 摂取量が異なるという結果が得られている ${ }^{7)}$. しかし, 職種やその他の労働状況によるコンビニを利用した食事 のエネルギー，脂質，糖分等の摂取量について明らかに された研究はない。よって, 本研究では若年労働者の食 生活に打けるコンビニを利用した食事摂取内容と労働状 況に関する実態について明らかにすることを目的とし， そこから生活習慣病予防, 特に肥満予防について検討し た。

\section{II. 研究方法}

1. 調查対象

輸送が主な業務である一企業の石川県内に勤務する 29 歳以下の労働者 284 人.

\section{2. 調查期間}

平成 18 年 10 月 1 日から 10 月 16 日.

\section{3. 調查方法}

独自に作成した質問紙を用いて，無記名自記式調査を 行った。質問紙の作成にあたっては，事前に対象企業の 若年労働者, 2 人にプレテストを行い, 対象者が回答し やすい質問方法を検討した，各部署の責任者を通して， 対象者各自に依頼書・質問紙・返信用封筒を配付した。 回収は，企業内の業務郵便を利用して企業の健診センタ ーで行った.

\section{4. 調查内容}

調查内容は，性，年齢，身長・体重，労働状況，食事 摂取内容（購入食品, 利用したコンビニ名, 利用した食 事), 食生活に対する意識とした。身長・体重について は, 対象者が申告した最近の值とした。食事摂取内容で は，設けられた調查期間内でコンビニを利用したある一 日のことについて回答を得た。また，労働状況について は，コンビニを利用した日の勤務における泊りの有無， 早出の有無, 拘束時間と, 業務形態について回答を得た.

購入食品の選択肢を作るにあたっては, 平成 18 年 8 月から 9 月にかけて市内の大手コンビニ 6 店舗で食品の 熱量と栄養素を調査し, さらに新外食テイクアウトのカ ロリーガイドブック ${ }^{8)}$ や，コンビニのホームページ 9) で公開されている情報に基づき, 熱量と栄養素の平均值 を算出し，15 分類 134 品目に設定した。

\section{5. 分析方法}

解析には, 統計解析ソフト HALBAU for Windows Version 5.34 を用いて $\chi^{2}$ 検定， t検定を行った。また， 一元配置分散分析を行い, Bonferroni 法により多重性を
考慮した。これらはすべて有意水準を $5 \%$ とした。

肥満予防の検討のために身長・体重から BMI を算出 し評価した。1999年に提唱された日本肥満学会の判定 基準は, 肥満を 25.0 以上としているが, 南里ら ${ }^{10)}$ はそ の基準では, 高脂血症, 高血糖, 高尿酸血症, 肝疾患の 異常が見られており, 体型の基準を少し厳しく 24.2 以 上を肥满としている，それを参考に，また若年であるこ とを考慮して本研究では, 肥満の兆候を軽度のうちから 捉えられるように, BMIが 24.0 未満を非肥満, BMIが 24.0 以上を過体重・肥満とした。

\section{6. 倫理的配慮}

企業の責任者に, 研究依頼書及び研究計画書を提出し, 文書と口頭で研究の主旨と概要を説明し, 調查の同意を 得た。質問紙は無記名とし，記入後は封筒に入れてもら うことで個人が特定されないようにした。また結果の公 表に際しては, 企業名・個人名が特定されないようにし, デー夕は厳重な管理の下で使用し, 研究終了後は確実に 破棄することを説明した。なお，本研究は金沢大学医学 倫理委員会の承認を得た後, 実施した。

\section{III. 結 果}

1. 質問紙の配付 ・ 回収状況

質問紙を 284 人に配付し，193 人から回答を得た（回 収率 $68.0 \%$ ). 有効回答数は 185 人 (有効回答率 $95.9 \%$ ) であった、質問紙のコンビニを利用した食事摂取内容に 欠損のないものを分析した.

2. 属性

性別は男性 160 人, 女性 25 人, 合計 185 人で, 平均 年齢は $24.0 \pm 2.6$ 歳（男性 $24.1 \pm 2.6$ 歳，女性 $24.0 \pm 2.6$ 歳) であった。

労働状況として対象となった労働者の業務形態は, 運 転業務（以下業務 A） 35 人 (19.0\%) 運転補助掞よび 接客販売業務 (以下業務 B) 45 人 $(24.5 \%)$, 施設内接 客販売業務 (以下業務C) 14 人 $(7.6 \%)$, 屋内 - 外作業 (以下業務 D) 64 人 $(34.7 \%)$, 事務業務（以下業務 E) 27 人 $(14.7 \%)$ であった. 対象者の中には, 泊りや早 出という不規則な勤務を持つ人がおり, 泊り・休憩を含 め, 拘束時間が平均 16.4 時間という特殊な勤務体制で ある。

1 週間のコンビニ利用日数について，0日の人は 38 人 $(21.3 \%)$ で, 週 1 日以上利用している人は 145 人 (78.7\%) であり，そのうち週に1〜3日利用している 人は 81 人 $(44.2 \%), 4 \sim 7$ 日利用している人が 64 人 $(34.4 \%)$ であった. 平均利用日数は 2.7 日であった. 
Table 1. Usage of convenience stores divided by working situations

\begin{tabular}{|c|c|c|c|c|c|c|c|c|}
\hline \multirow{2}{*}{\multicolumn{2}{|c|}{ Working situations }} & \multicolumn{2}{|c|}{ Men } & \multicolumn{2}{|c|}{ Women } & \multicolumn{3}{|c|}{ Users or non-users convenience store } \\
\hline & & $\mathrm{n}$ & $\mathrm{Age}^{\dagger}$ & $\mathrm{n}$ & $\mathrm{Age}^{\dagger}$ & Users (\%) & Non-users (\%) & \\
\hline \multirow{5}{*}{$\begin{array}{l}\text { Working type } \\
\mathrm{n}=185\end{array}$} & Type A & 33 & $24.5 \pm 1.6$ & 2 & $23.0 \pm 1.4$ & $32(91.4)$ & $3(8.6)$ & \multirow{5}{*}{$*$} \\
\hline & Type B & 38 & $23.7 \pm 2.3$ & 7 & $21.6 \pm 1.5$ & $41(91.1)$ & $4(8.9)$ & \\
\hline & Type C & 4 & $24.3 \pm 3.0$ & 10 & $24.9 \pm 2.5$ & $13(92.9)$ & $1(7.1)$ & \\
\hline & Type D & 62 & $23.0 \pm 2.5$ & 2 & $24.5 \pm 4.9$ & $46(71.9)$ & $18(28.1)$ & \\
\hline & Type E & 23 & $27.0 \pm 1.9$ & 4 & $26.0 \pm 1.4$ & $14(51.9)$ & $13(48.1)$ & \\
\hline \multirow{2}{*}{$\begin{array}{l}\text { Night duty } \\
\mathrm{n}=178\end{array}$} & Yes & 71 & $24.3 \pm 2.3$ & 10 & $21.9 \pm 1.4$ & $72(88.9)$ & $9(11.1)$ & \multirow{2}{*}{$*$} \\
\hline & No & 83 & $23.7 \pm 2.7$ & 14 & $24.0 \pm 2.6$ & $68(70.1)$ & 29 (29.9) & \\
\hline \multirow{2}{*}{$\begin{array}{l}\text { Early attendance } \\
n=177\end{array}$} & Yes & 16 & $23.4 \pm 2.0$ & 3 & $25.7 \pm 0.6$ & 18 (94.7) & $1(5.3)$ & \multirow{2}{*}{$p=0.069$} \\
\hline & No & 137 & $24.1 \pm 2.6$ & 21 & $23.7 \pm 2.7$ & $121(76.6)$ & 37 (23.4) & \\
\hline \multirow{2}{*}{$\begin{array}{l}\text { Work time } \\
\mathrm{n}=177\end{array}$} & Under $12 \mathrm{~h}$ & 66 & $23.2 \pm 2.5$ & 10 & $25.0 \pm 2.3$ & $52(65.8)$ & 27 (34.2) & \multirow{2}{*}{ * } \\
\hline & Over $12 \mathrm{~h}$ & 87 & $24.6 \pm 2.5$ & 14 & $22.9 \pm 2.3$ & 87 (88.8) & $11(11.2)$ & \\
\hline
\end{tabular}

*: $p<0.05$; Significant difference between users and non-users.

${ }^{\dagger}$ : Age is shown as arithmetic mean \pm standard deviation.

3. 労働状況別のコンビニ利用の有無

対象者全体でコンビニ利用有りは 146 人 $(78.9 \%)$, コンビニ利用無しは 38 人 $(21.1 \%)$ であった。業務形 態によってコンビニ利用の有無に有意差がみられた。利 用有りの割合は「業務 A・B・C」では $90 \%$ 超えて いた。泊りの有無では，「泊り有」の方が利用有りの割 合は有意に高かった。早出の有無には有意差はなかった。 拘束時間では「12 時間以上」の方がコンビニの利用有 りの割合が有意に高かった。どの労働状況の結果におい ても，コンビニの利用有りの割合は，利用無しの割合よ り高かった（Table 1).

\section{4. 労働状況別のコンビニを利用した食事摂取内容}

業務形態別の食事摂取内容は，「業務 $\mathrm{B} 」$ は「業務 $\mathrm{C}$ より朝食の平均炭水化物が有意に多い。「業務 C」は, 朝食で平均熱量が低いが，昼食・夕食では他の業務より も高くなっている（Table 2)，泊りの有無では朝食の平 均炭水化物が「泊り有」の方が有意に多い。早出の有無 では，コンビニを利用した食事摂取内容に有意差はみら れなかったが，平均熱量はすべての食事で「早出有」の 方が高い傾向がみられた。拘束時間では，コンビニを利 用した食事摂取内容に有意差はみられなかった。全体的 に，朝食の平均熱量はどの食事よりも低く，朝食から夕 食にかけて平均熱量・蛋白質が高くなっていく傾向がみ られた。

業務形態別のエネルギー比率では，標本数 1 の昼食の

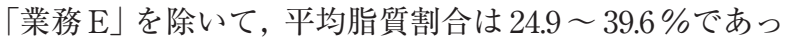
た（Fig. 1)。その他の労働状況においても，泊りの有 無では $25.2 \sim 33.3 \%$ (Fig. 2)，早出の有無では 26.0〜 $36.1 \%$ (Fig. 3)，拘束時間では $25.5 〜 33.2 \%$ (Fig. 4) であり，ほとんどの労働状況で平均脂質割合が $25 \%$ を
超えていた.

5. BMI 別のコンビニ利用の有無・食事摂取内容

対象者の BMI の平均值は $23.1 \pm 4.2$ (男性 $23.4 \pm 4.3$,

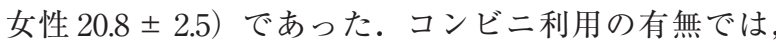
$\lceil\mathrm{BMI} 24.0$ 未満 (非肥満)」のコンビニを利用している人 は 97 人 $(75.2 \%)$, 利用していない人は 32 人 $(24.8 \%)$ で「BMI24.0 以上（過体重・肥満）」のコンビニ利用者 は 47 人 $(87.0 \%)$ ，利用していない人は 7 人 $(13.0 \%)$ で，有意差はなかった。しかし平均脂質割合はいずれも $25 \%$ 超えていた。

6.コンビニを利用して食事を 3 食以上摂取した人 コンビニを利用して朝食・昼食・夕食の 3 食を摂取し た人，それらの食事に加え間食・夜食を摂取した人は， 合わせて 11 人であった（以下「3 食以上摂取した人」 とする)。これはコンビニ利用者の $7.5 \%$ を占め，全員 男性であった。「3 食以上摂取した人」の労働状況は業 務 $\mathrm{A}$ は 3 人，業務 $\mathrm{B}$ は 5 人，業務 $\mathrm{D}$ は 3 人で業務 $\mathrm{C}, \mathrm{E}$ には 3 食以上摂取した人はいなかった。「泊り有」は 6 人,「泊まり無」は 5 人,「早出有」は 2 人,「早出無」 は 9 人であり，拘束時間について $\lceil 12$ 時間未満」は 3 人， $\lceil 12$ 時間以上」が 8 人であった。熱量, 各栄養素の平均 值は熱量 2,162.5 kcal, 蛋白質 $60.5 \mathrm{~g}$, 脂質 $67.3 \mathrm{~g}$, 炭水 化物 $327.8 \mathrm{~g}$ であった。 そのエネルギー比率は, 蛋白質 割合 $11.2 \%$, 脂質割合 $28.0 \%$, 炭水化物割合 $60.6 \%$ で あった。また，「3 食以上摂取した人」の BMI は，平均 值 $24.4 \pm 4.1$ であった。

7. 食生活に対する意識

1 週間のコンビニの利用日数により食生活に対する意 
Table 2. Volumes of the energy, protein, fat and carbonhydrate taken in by using convenience stores divided by working situations

\begin{tabular}{|c|c|c|c|c|c|c|c|c|c|c|c|}
\hline \multirow{2}{*}{\multicolumn{2}{|c|}{ Working situations }} & \multicolumn{5}{|c|}{ Breakfast } & \multicolumn{5}{|c|}{ Lunch } \\
\hline & & $\mathrm{n}$ & E (kcal) & $\mathrm{P}(\mathrm{g})$ & $\mathrm{F}(\mathrm{g})$ & C (g) & $\mathrm{n}$ & E (kcal) & $\mathrm{P}(\mathrm{g})$ & $\mathrm{F}(\mathrm{g})$ & $\mathrm{C}(\mathrm{g})$ \\
\hline \multirow{5}{*}{ Working type } & Type A & 13 & $454.9 \pm 215.4$ & $12.4 \pm 6.4$ & $15.5 \pm 10.4$ & $66.0 \pm 29.7$ & 19 & $777.3 \pm 294.3$ & $23.0 \pm 9.0$ & $24.5 \pm 13.3$ & $116.0 \pm 40.2$ \\
\hline & Type B & 17 & $490.7 \pm 202.1$ & $12.6 \pm 6.1$ & $16.1 \pm 10.5$ & $73.5 \pm 30.2 \neg$ & 25 & $704.9 \pm 231.2$ & $20.0 \pm 7.5$ & $20.2 \pm 11.0$ & $110.4 \pm 37.6$ \\
\hline & Type C & 4 & $212.0 \pm 133.5$ & $7.0 \pm 4.9$ & $9.3 \pm 8.5$ & $24.7 \pm 14.8$ & 10 & $817.0 \pm 314.4$ & $23.3 \pm 10.4$ & $26.6 \pm 15.2$ & $120.3 \pm 44.9$ \\
\hline & Type D & 32 & $417.0 \pm 173.0$ & $11.1 \pm 5.1$ & $15.0 \pm 9.3$ & $59.1 \pm 27.5$ & 14 & $629.3 \pm 362.3$ & $18.5 \pm 10.1$ & $17.4 \pm 11.1$ & $100.0 \pm 60.9$ \\
\hline & Type E & 7 & $527.3 \pm 269.1$ & $13.9 \pm 8.7$ & $21.4 \pm 13.7$ & $69.8 \pm 32.4$ & 1 & 522.0 & 16.5 & 7.8 & 96.2 \\
\hline \multirow{2}{*}{ Night duty } & Yes & 26 & $504.0 \pm 235.7$ & $13.4 \pm 7.0$ & $17.4 \pm 12.3$ & $73.1 \pm 32.3$ & 40 & $693.1 \pm 207.5$ & $20.3 \pm 6.7$ & $19.4 \pm 10.4$ & $109.1 \pm 33.1$ \\
\hline & No & 43 & $413.0 \pm 177.9$ & $11.0 \pm 5.4$ & $15.3 \pm 9.3$ & $57.4 \pm 27.7$ & 25 & $775.1 \pm 389.7$ & $22.1 \pm 11.9$ & $24.3 \pm 15.0$ & $116.8 \pm 59.1$ \\
\hline \multirow{2}{*}{$\begin{array}{l}\text { Early } \\
\text { attendance }\end{array}$} & Yes & 7 & $510.9 \pm 127.5$ & $14.0 \pm 4.1$ & $20.5 \pm 6.7$ & $67.1 \pm 22.5$ & 14 & $859.1 \pm 321.7$ & $23.0 \pm 10.1$ & $26.4 \pm 14.7$ & $131.9 \pm 44.1$ \\
\hline & No & 61 & $444.4 \pm 215.0$ & $11.6 \pm 6.2$ & $15.9 \pm 10.8$ & $63.5 \pm 31.5$ & 51 & $687.7 \pm 274.2$ & $20.4 \pm 8.8$ & $19.9 \pm 11.6$ & $106.6 \pm 43.6$ \\
\hline \multirow{2}{*}{ Working time } & Under $12 \mathrm{~h}$ & 34 & $434.1 \pm 188.0$ & $11.4 \pm 5.1$ & $16.0 \pm 9.6$ & $60.8 \pm 29.5$ & 18 & $709.9 \pm 404.1$ & $21.0 \pm 12.9$ & $22.7 \pm 15.0$ & $105.6 \pm 61.9$ \\
\hline & Over $12 \mathrm{~h}$ & 34 & $468.4 \pm 227.7$ & $12.3 \pm 6.9$ & $16.7 \pm 11.5$ & $66.9 \pm 31.7$ & 47 & $730.3 \pm 239.9$ & $21.0 \pm 7.2$ & $20.7 \pm 11.6$ & $114.5 \pm 36.4$ \\
\hline \multirow{2}{*}{\multicolumn{2}{|c|}{ Working situations }} & \multicolumn{5}{|c|}{ Dinner } & & & & & \\
\hline & & $\mathrm{n}$ & E (kcal) & $\mathrm{P}(\mathrm{g})$ & $\mathrm{F}(\mathrm{g})$ & $\mathrm{C}(\mathrm{g})$ & & & & & \\
\hline \multirow{5}{*}{ Working type } & Type A & 23 & $774.1 \pm 290.9$ & $23.0 \pm 9.4$ & $23.9 \pm 10.9$ & $115.8 \pm 47.3$ & & & & & \\
\hline & Type B & 25 & $845.9 \pm 242.4$ & $25.3 \pm 9.1$ & $23.4 \pm 10.8$ & $132.2 \pm 36.1$ & & & & & \\
\hline & Type C & 4 & $935.4 \pm 278.1$ & $29.6 \pm 2.2$ & $28.6 \pm 9.5$ & $139.3 \pm 47.6$ & & & & & \\
\hline & Type D & 18 & $782.2 \pm 326.6$ & $24.3 \pm 12.2$ & $25.3 \pm 14.4$ & $114.1 \pm 45.6$ & & & & & \\
\hline & Type E & 8 & $755.1 \pm 288.4$ & $23.2 \pm 12.5$ & $25.1 \pm 12.5$ & $108.5 \pm 40.2$ & & & & & \\
\hline \multirow{2}{*}{ Night duty } & Yes & 47 & $824.5 \pm 282.1$ & $23.9 \pm 9.3$ & $24.1 \pm 10.9$ & $127.1 \pm 45.0$ & & & & & \\
\hline & No & 27 & $798.4 \pm 292.6$ & $26.2 \pm 11.8$ & $26.0 \pm 13.2$ & $114.2 \pm 41.8$ & & & & & \\
\hline \multirow{2}{*}{$\begin{array}{l}\text { Early } \\
\text { attendance }\end{array}$} & Yes & 9 & $822.6 \pm 176.1$ & $26.3 \pm 10.6$ & $27.4 \pm 8.5$ & $116.2 \pm 22.7$ & & & & & \\
\hline & No & 66 & $805.5 \pm 302.8$ & $24.2 \pm 10.4$ & $24.1 \pm 12.2$ & $122.1 \pm 46.9$ & & & & & \\
\hline \multirow{2}{*}{ Working time } & Under $12 \mathrm{~h}$ & 18 & $811.4 \pm 329.3$ & $25.2 \pm 12.5$ & $26.3 \pm 15.2$ & $118.4 \pm 43.9$ & & & & & \\
\hline & Over $12 \mathrm{~h}$ & 57 & $806.3 \pm 279.2$ & $24.2 \pm 9.7$ & $24.0 \pm 10.7$ & $122.3 \pm 45.2$ & & & & & \\
\hline
\end{tabular}

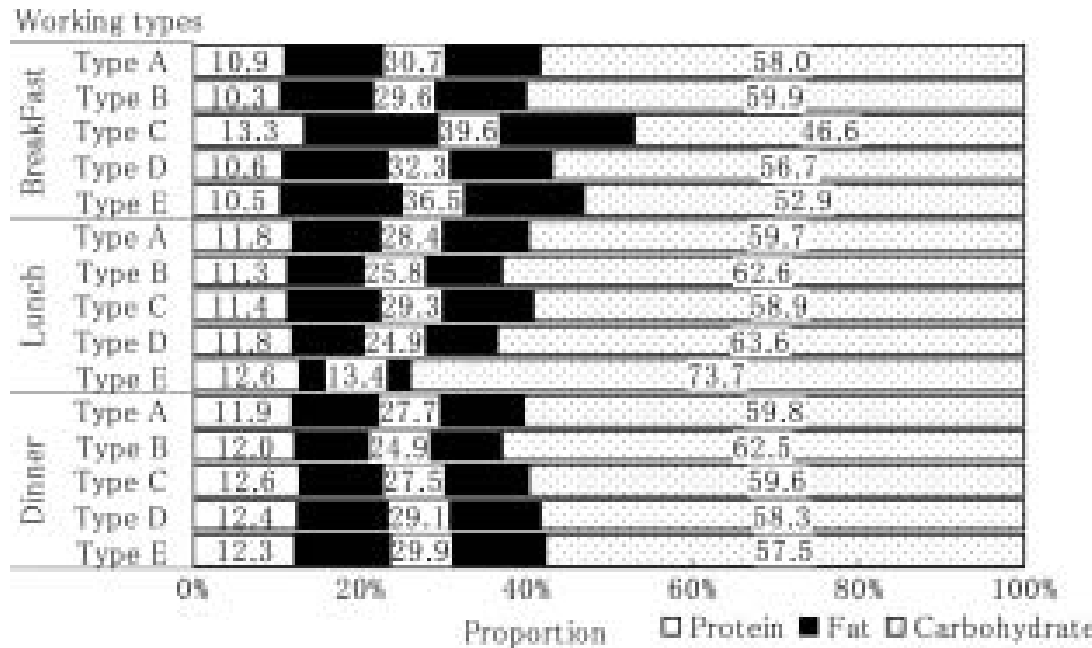

Fig. 1. The proportion of the energy in by using convenience stores dividied by working types. The proportion of the energy is shown as ration about protain, fat and carbohydrate. 


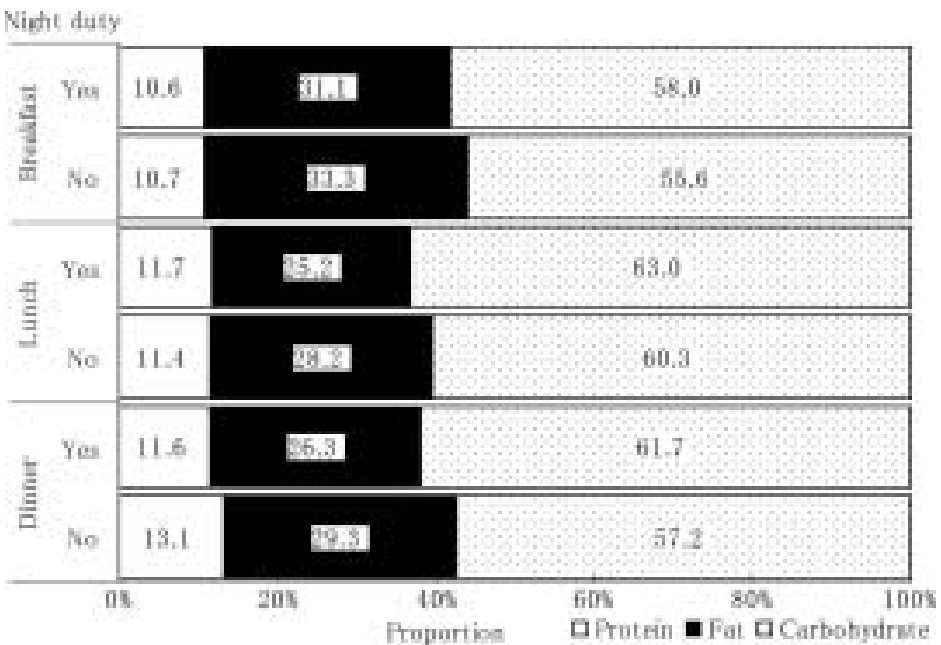

Fig. 2. The proportion of the energy in by using convenience stores divided by night duty. The proportion of the energy is as shown as ration about protein, fat and carbohydorate.

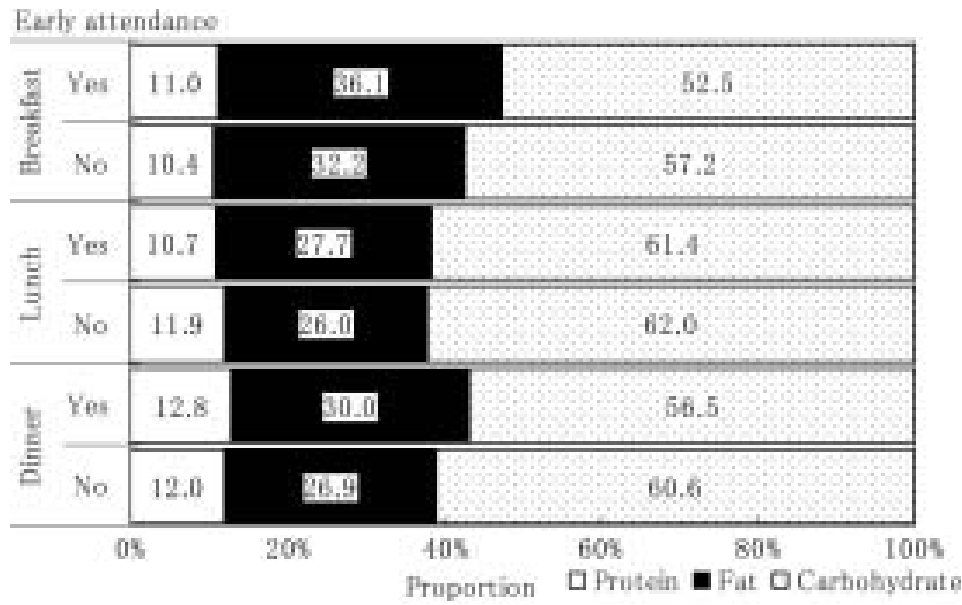

Fig. 3. The proportion of the energy in by using convenience stores divided by early adeptance. The proportion of the energy is shown as ration about protain, fat and cabohydrate.

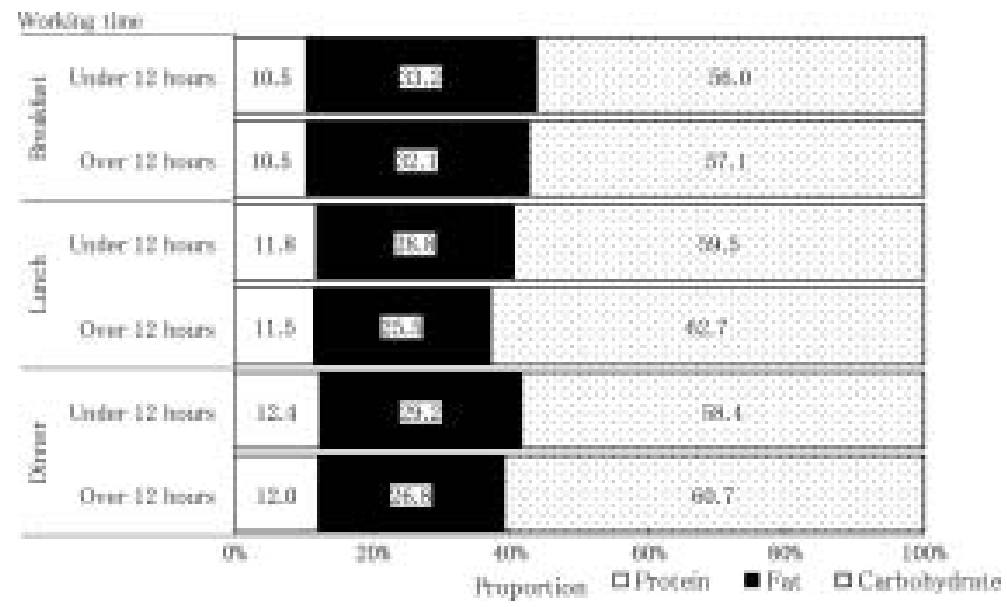

Fig. 4. The proportion of the energy in by using convenience storer divided by working times. The propotion of the energy is shown as ration about protain, fat and carbohtdrate. 
Table 3. Cognition about the diet habit in days using convenience stores for a week

\begin{tabular}{|c|c|c|c|c|}
\hline \multirow{2}{*}{ Cognition about the diet habit } & \multicolumn{4}{|c|}{ Days using convenience stores for a week } \\
\hline & 0 day $(\%)$ & $1 \sim 3$ days $(\%)$ & $4 \sim 7$ days $(\%)$ & \\
\hline Need to improve & $14(36.8)$ & 49 (64.5) & $54(90.0)$ & \\
\hline As it stands & $20(52.6)$ & $11(14.5)$ & $3(5.0)$ & $*$ \\
\hline Neither & 4 (10.5) & $16(21.1)$ & $3(5.0)$ & \\
\hline Total & $38(100)$ & $76(100)$ & $60(100)$ & \\
\hline
\end{tabular}

$*: p<0.05$.

識に有意差がみられた。利用日数が「0日」の人は食生 活について「このままでよいと思う」と考えている人が 20 人 $(52.6 \%)$ と最も多かった。一方でコンビニを利 用している人では「改善が必要だと思う」と考えている 人が最も多かった。利用日数別では「1 3 日」で 49 人 $(64.5 \%),\lceil 4 \sim 7$ 日」で 54 人 $(90.0 \%)$ であり, コン ビニの利用日数が多いほど「改善が必要だと思う」と考 えている人の割合が有意に高くなっていた（Table 3).

\section{N. 考 察}

本研究の対象者の週 3 日以上コンビニを利用する人の 割合は $54.6 \%$ で半数以上であった。この結果は 20 歳代 では $47.1 \%$ が週 3 日以上コンビニを利用している ${ }^{6)}$ と いう報告と同様であり, 若年者の食生活の特徴が反映さ れた結果であった。

労働状況とコンビニ利用の有無に関連がみられたの は, 泊りの勤務や拘束時間が 12 時間以上であった。こ の結果の解釈として長時間に及ぶ勤務では家庭の弁当は 保存ができないこと，決まった時間に食事を摂ることが できないことが影響していたと考えられる。さらに，コ ンビニには手軽で好きな時間に利用できるという利便性 がある.このようなコンビニの利便性が拘束時間が長く, 不規則な労働状況に合っており, 若年労働者の食事を支 えているのではないかと考えられる.

業務形態では朝食の平均炭水化物で「業務 $\mathrm{B} 」 と 「$ 業 務 C」に有意差がみられたが，「業務C」の標本数が少 なく, 正確に業務形態の実態を反映しているとは言い難 い. 泊りの有無に扔いては朝食の平均炭水化物に有意差 がみられたが，特徴は見出せなかった．全体的に労働状 況とコンビニを利用した食事摄取内容に有意差がみられ たものが少なかった。それは若年労働者のコンビニを利 用した食事摄取内容には，労働状況による影響より，労 働者の嗜好等今回調查していない個人的な要因の方が大 きく関わっていたのではないかと考えられる.

今回の調查では，業務別による活動量や消費エネルギ 一まで詳細な調査はしていないが, 業務 A の運転業務 や業務 $\mathrm{E}$ の事務業務と業務 Dのような作業系業務とは
労作の程度が異なることが推測できる．事務系職種のほ

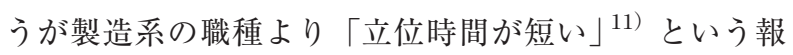
告もあり，消費エネルギーに差がある可能性がある。し かし，本研究の結果では業務による摂取エネルギーには 明らかな差は見出されておらず，これは若年労働者が自 己の労働による消費エネルギーから考えられる摂取エネ ルギーや栄養素の適正量を考慮せず, 食品を選択してい るとも考元られる。

BMIによって評価した肥満とコンビニ利用の有無, コンビニを利用した食事摂取内容には関連がみられな かった。 その要因として，20歳代では生活習慣は悪い が身体的健康度はよかった ${ }^{12)}$ という報告もあり, 今回 の対象である若年労働者には, 現時点では顕著にBMI による肥満が現れる年齢層とはいえなかったことが考え られる。また，コンビニを利用した食事に限定し対象者 の食事全体を把握していなかったことも要因として挙げ られる.

しかし, コンビニの食品の特徵には脂質割合が高い ${ }^{13}$ という報告があり，本研究でも，摃取された頻度が高 かったコンビニの食品では脂質割合が高いものが多いこ とがわかった。また，どの労働状況においてもコンビニ を利用して撖取された朝食・昼食・夕食の平均脂質割合 が1日の適正範囲とされる $20 \sim 25 \%{ }^{14)}$ を超えている ものが多かった．食事摂取内容を評価するためには，1 日の食事全体を把握する必要があるが，今回の調查では コンビニの食品以外に摂取した食事全体を把握していな い. さらに, 食事 1 食を 1 日分の食事の適正範囲と比較 しているが, 脂質割合が高いコンビニの食事が積み重な ることによって 1 日分の食事の脂質割合が適正範囲を超 えることが予測される.コンビニを利用して1日の食事 を㠌取したと考えられる「3 食以上摂取した人」では, 摂取した平均脂質割合が $28.0 \%$ であり, 適正範囲の上 限である $25 \%$ ，さらに全国の 20 歳代の男性の平均脂肪 エネルギー比率 $27.1 \%{ }^{14)}$ を超えている. BMIでは全国 の 20 歳代の男性の平均值が $22.5^{14)}$ であるのに対し,「3 食以上撕取した人」の平均值は 24.4 とさらに高いこと から，コンビニを利用した食事で脂質割合の高い食品を 
摂取し続けることで肥満のリスクが高まる可能性が考え られる。

コンビニを利用する一方で 1 週間のコンビニ利用日数 が多くなるほど, 食生活に対して「改善が必要だと思う」 と考えている人の割合が有意に高くなっていた.これは， 対象者がコンビニを利用している食生活について改善が 必要であると感じていると考えられ，若年者の健康意識 と健康行動・健康習慣には大きな隔たりがあり，健康意

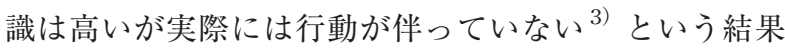
と一致しているといえる。これは，コンビニを利用する 食生活を改善したいという意識を持っているが，不規則 な勤務やコンビニという利用のしやすさが影響し，その 意識に伴った行動がとれていないと考えられる.

以上より，コンビニを利用する若年労働者に，肥満の リスクが高まることを予防できる食生活の支援をする必 要があると考える。コンビニを利用した食事では脂質割 合の高い食品を摃取しやすいという実態が明らかになっ た。よって, 若年労働者が自己の労働に伴う消費エネル ギーに見合った食事摂取内容の理解と，不規則な勤務体 制の中でのコンビニの利用方法を考えられるような保健 指導が必要であると考える。 そして，コンビニを利用す る際には栄養表示を確認しながら食品を選択できるよう な支援をしていくことが求められる。それにより, 若年 のうちからコンビニを利用した食事を掑取しながらも， 肥満のリスクを軽減し生活習慣病の予防につなげられる と考える. しかし, 栄養表示がされていない食品もある ため, 店頭に並ぶすべての食品の熱量と各栄養素を表示 することをコンビニ側に働きかけ，若年労働者が情報を 入手しやすい環境を整えることも必要である.

\section{V. まとめ}

労働状況とコンビニを利用した食事摂取内容には，明 らかな関連はなかったが，ほとんどの労働状況で平均脂 質割合が $25 \%$ 超えて打り，肥満のリスクが予測され た，さらに，コンビニを利用している食生活について改 善が必要であると感じていると考えられた。よって, 若 年労働者が自己に見合った食事摂取内容や，コンビニの 利用方法を理解し，栄養表示を確認して食品を選択でき るような支援と, 食品に栄養表示がされるようコンビニ 側に働きかけ，食品の情報を入手しやすい環境を整える 必要があるといえる.

謝辞：本研究を進めるにあたり，貴重な時間を割いて快 く調査にご協力いただきました企業の皆様，及び，調査 の調整や実施等にご協力くださいました健診センターの 皆様に心から感謝いたします。

\section{文献}

1）白石康子，鳥居順子，宮内清子，ほか. 若年勤労男性の生 活習慣の特徴および肥満との関連. 愛媛県立医療技術短期 大学紀要 1999; 12: 61-65.

2）高瀬悦子, 田畑正司, 由田克士, ほか. 一企業の若年労働 者における食物摂取習慣と食品摂取習慣頻度および健康診 断結果との関連. 北陸公衆衛生学雑誌 2002; 28: 81-88.

3）近藤淳子, 山内恵美, 白石康子, ほか. 若年男性の健康意 識と生活習慣の関係. 第 30 回日本看護学会論文集一地域 看護学— 1999; 30: 101-103

4）和井内英樹. 若年成人男性の入社後の体重変動. 肥満研究 2003; 9: 58-63.

5）経済産業省経済産業政策局. 商業統計調查. 2006. (online), available from <http://www.meti.go.jp/statistics/shougyou/2004niji/gyoutai7.pdf>, (accessed 2006-05-29).

6）社会法人中央調査社. 全国成人のコンビニエンスストア利 用状況. 2001. (online), available from <http://www.crs.or. jp//pdf/cvs.pdf $>$, (accessed 2006-05-29).

7）大脇淳子, 栗栖陽子, 和田郁江, ほか. 作業系職種と事務 系職種の食物および各種栄養素摂取量の相違. 日本公衆衛 生雑誌 2001; 48: 879-888.

8）香川芳子. コンビニ・市販食品編ホットデリカ 新外食テ イクアウトのカロリーガイドブック 外食・テイクアウト 編/コンビニ・市販食品編. 東京：女子栄養大学出版部, 2002: 162-163.

9) Family Mart. 商品情報栄養成分値. (online), available from <http://www.family.co.jp/goods/safety>, (accessed 2006-08-07).

10）南里明子, 早㴊仁美, 梅木陽子, ほか. 福岡女子大学人間 環境学部紀要 2003; 34: 53-60.

11）山崎富浩. 若年男性を中心として職域集団における生活習 慣, 作業姿勢, および職種が BMI 変化割合に与える影響. 日本公衆衛生学会誌 1995; 42: 1042-1053

12）福田吉治, 渡辺マサ子, 阿津佐和子, ほか. ライフスタイ ルと健康一成人男性の年齢階級別保健指導方法についての 検討 [1] RIDIT 分析を用いた生活習慣と健康. 保健婦雑 誌 1996; 3: 190-195.

13）押野榮司. 外食利用の注意点. からだの科学 2006；249: 68.

14）厚生労働省健康局総務課生活習慣病対策室. 平成 16 年国 民健康・栄養調查結果の概要. (online), available from <http://www.mhlw.go.jp/houdou/2006/05/h0508-1a. html>, (accessed 2006-06-27).

【参考】質問紙に用いた質問項目（ただし，解答欄は略す）

1. 年齢

2. 性別

3. 身長, 体重 (一番最近の数值を記入して下さい)

4. どの仕事に従事していますか.

5. 勤務に泊まりはありますか.

6. 勤務に早出 $(7: 30$ 以前）ありますか.

7. 1 週間のうちに何日, 食品を買うためにコンビニエンスス トアを利用しましたか。

8. 1 週間で仕事がある日のうち, 食品を買うためにコンビニ 
エンスストアを利用した日のいずれか 1 日についてお答え

ください（選択肢よりコンビニの食品とコンビニ名を選択

してもらう)

9.8で回答した日の勤務時間についておうかがいします。そ の日の勤務が始まった時間と, 終わった時間を記入してく
ださい.

10.コンビニエンストアを利用されていない方は，一番最近勤 務があった日の，勤務が始まった時間と，終わった時間を 記入してください。

11. 今の食生活についてどのように考えていますか.

\title{
Examination of the Relationship between the Working Conditions of Young Workers and the Content of the Meals They Buy at Convenience Stores
}

\author{
Miki Miyagoshi ${ }^{1}$, Mika Otsuka ${ }^{2}$, Megumi Kato ${ }^{3}$, Chiharu Kubo ${ }^{4}$, Kayoko Tsuchihashi ${ }^{5}$, Hiromi Toyoshima ${ }^{6}$, \\ Eriko MiYAZAkI ${ }^{7}$, Ayumu Yoshie ${ }^{8}$, Mika OKURA ${ }^{9}$, Shizuko OmOTE ${ }^{9}$ and Teruhiko KIDo ${ }^{9}$ \\ ${ }^{1}$ Kanazawa University Graduate School of Medical Science Division of Health Sciences, 5-11-80 Kotatsuno, Kanazawa-city, \\ Ishikawa 920-0942, Japan, ${ }^{2}$ Kanazawa Motomachi Health and Welfare Center, ${ }^{3}$ Kanazawa University Hospital, ${ }^{4}$ Kanazawa \\ Arimatsu Hospital, ${ }^{5}$ Kyoto Prefecture University of Medicine, ${ }^{6}$ Notohokubu Health Center, ${ }^{7}$ Kanazawa Ekinishi Health and \\ Welfare Center, ${ }^{8}$ Osaka Red Cross Hospital and ${ }^{9}$ Kanazawa University Institute of Medical, Pharmaceutical and Health Sciences \\ Division of Health Sciences
}

\begin{abstract}
The aim of this study was to investigate the relationship between the working conditions of young workers and the meals they buy at convenience stores, and to consider the prevention of obesity. The subjects of this study were 284 workers under $29 \mathrm{yr}$ of age employed at a transportation company in Ishikawa prefecture. Questionnaires were sent to participants, and 193 valid responses were obtained. Working types, night duty and working time were correlated with convenience store patronage, although working situations were not obviously associated with the content of meal selection at convenience stores. The study results revealed a tendency for the proportion of the fat in meals to be greater than $25 \%$
\end{abstract}

for the majority of working situations. It was also shown that foods selected with high frequency contained a high proportion of fat. There results suggest that this situation increases the risk of obesity. In addition, the more days per week convenience stores were patronized, the greater the number of participants felt "The need to improve meals." Therefore, we believe it is essential that young workers consider the prevention of obesity by observing nutritional information when selecting foods. An environment in which such information is easy to obtain at convenience stores should be arranged.

(San Ei Shi 2008; 50: 92-99) 